\title{
THE IMPROVEMENT OF THE SERVICES QUALITY THROUGH DEVELOPMENT of Teachers Personality and Organizational Justice
}

\author{
Kania Rubiati $^{1)}$, Sri Setyaningsih ${ }^{2),}$,Henny Suharyati ${ }^{3)}$ \\ ${ }^{1), 2), 3)}$ Universitas Pakuan, Bogor, Indonesia \\ E-mail: henny.suharyati@unpak.ac.id
}

\begin{abstract}
The quality of teacher services is an important element related to achieving national education goals and developing Indonesian people as a whole. The initial survey of teacher service quality in the Civil Servants in the High School in the city of Bogor has not yet reached maximum results. Therefore, the quality of teacher services is interesting to study. This study aims to find efforts to improve teacher service quality by examining the relationship between teacher service quality with teacher personality variables and organizational justice. The data needed in this study were captured using an instrument in the form of a questionnaire. Before the questionnaire is used as a data collection tool, it must be first analyzed its validity and reliability. This analysis was carried out by testing the instrument to respondents, who had been determined. This trial is intended to determine the feasibility of this instrument as a research instrument. The study also uses correlational statistical methods and analysis of the SITOREM method. The unit of research analysis was a high school civil servant teacher with a population of 279 and a sample of 103 teachers. The results of the study show there is a positive relationship between the teacher's personality and the quality of teacher services with the strength of the relationship ry $_{1}=0.421$ and there is a positive relationship between organizational justice and the quality of the teacher's service with the strength of the $\mathrm{ry}_{2}=0.297$ so that the quality of teacher service can be improved through the personality of the teacher and organizational justice. The results of this study indicate that there is a relationship between the teacher's personality and the service quality approach as well as the organizational justice variable with the quality of teacher service both individually and collectively. SITOREM analysis results showed that there should be priority improvements to indicators that are not optimal such as (1) stable emotions (2) open to experience (3) procedural fairness (4) responsiveness (5) attention.
\end{abstract}

Keywords: Teacher Service Quality; Teacher Personality; Organizational Justice

\section{INTRODUCTION}

In the era of the Industrial Revolution 4.0, teachers need to improve their competence and quality. Especially with the current era of all-digital competition, not only preparing students but competently teachers must improve their quality. With the progress of information technology at this time teachers are asked not only to transfer knowledge but must instill the basic values of character development of students in the wise use of advances in information technology. Professional teachers who can take advantage of the superfast advances in information technology are needed to improve the quality of the teaching and learning process in each education unit to prepare superior human resources in global competence.

The quality of human resources cannot be separated from the quality of education, where one of the main components is the teacher. Quality schools are closely related to the provision of quality education services. Therefore, a teacher with high qualifications, competence, and dedication is needed in carrying out their professional duties. Teachers of Civil Servants (PNS) are state officials in charge of providing services to the community in a professional, honest, fair, and equitable manner in carrying out state, government, and development tasks.

Service quality is a form of consumer assessment of the level of service received (perceived service) with the level of service expected (expected service). Public trust of education service users is closely related to the quality of service in the school organization. The level of trust is built through the service relationship of the teaching staff, in this case, the teacher, to their students. The quality of teacher service is related to trust, which essentially provides the best service to students, parents, and the surrounding community.

The importance of a good teacher personality can influence the quality of teacher services in schools. The 
existence of dissatisfaction with organizational justice in schools also greatly determines the level of service or responsibility of a person in carrying out their duties. Therefore, the urgency of this study is to describe the development of a model of two factors, namely personality, and proper organizational justice so that the two variables can create an increase in service quality.

According to Kotler (2000), service quality is the ratio between the quality received (perceived quality) after receiving the expected quality (expected quality). Meanwhile, Baines, Fill, and Page (2011) said that service quality is the customer's perception of the difference between the service received compared to the expected service. Hussain (2010), service quality is a model to identify differences between consumer expectations for service and their assessment of the service received. Van Ree (2009) said that service quality is an assessment of how well the level of service provided is following customer expectations. Nagabushanam (2013), service quality is a term used in business administration which describes the achievement in service on the objective side and the subjective side of the service, namely customer expectations for services received with the ability to provide services by service providers. According to Yosliogu, Caliskan, and Omer (2013), service quality is a comparison between expected service and actual performance. Rabbai and Gable (2012) stated that service quality was developed to assess the gap between customer expectations and the level of service quality provided. Peter and Donnely (2011) described that service quality is a comparison made by customers between the service received and the service expected.

It can be synthesized that the quality of teacher service is the comparison between expected service and actual performance to meet customer expectations, especially students. Service quality indicators are divided into five, namely (a) teacher's physical appearance (b) teacher reliability (c) responsiveness (d) teacher assurance (e) teacher attention.

Gibson et al. (2012) said that personality is a set of characteristics, tendencies, and temperaments (relatively stable individuals) that have been significantly shaped by inheritance and by social, cultural, and environmental factors. Suzane, Dowd, and Scheneider (2006) stated that a personality is a group of stable characters, tendencies, and temperaments that are formed either from heredity or socio-cultural environmental factors. Kreitner and Kenicki (2007), personality is defined as a combination of physical and mental characteristics of a person who is stable as his identity. Greenberg and Baron (2008), personality is a pattern of behavior, thoughts, and emotions of individuals that are unique and relatively stable.

According to Colquitt, Lepine, and Wesson (2011), teacher personality refers to structures and tendencies in people that explain their distinctive patterns of thought, emotion, and behavior According to Helriegel and Scolum (2011), personality is an overall profile or combination of stable psychological attributes which is a unique trait of a person. Crae and Costa (2012) said that personality is a dimension of individual differences in the tendency to show consistent patterns of thoughts, feelings, and actions.

Based on the opinions of several experts, personality can be synthesized, which are unique and relatively stable individual characters, behavior patterns, thoughts, and emotions with indicators (a) sincerity (b) open to experience (c) enthusiasm (d) consensus (e) stable emotions.

Demirel and Yucel (2013) defined organizational fairness as a perception of people who compare their results and input with others and then assess the equality of this relationship in the form of a ratio. Akanbi, Ofoegbu, and Eugene (2013) said that organizational justice refers to employees who feel treated fairly by the organization in every aspect. Green and Baron (2008) defined organizational justice as the perception of organizational members towards justice that occurs within the organization.

Robbins and Judge (2009), most employees evaluate how fairly employees are treated by the organization. Baldwin (2006) defined organizational justice as the extent to which employees feel that work procedures, workplace interactions, and work results can be addressed fairly. Colquitt, Lepine, and Wesson (2015), organizational justice is an employee assessment of the fairness or fairness of decisions that have been made by the authorities. Gibson et al. (2012), organizational justice is the high and low degree or intensity of a person's feelings for the fair treatment they receive in the workplace. Kreitner and Kenicki (2007) stated that school, organizational justice reflects the extent to which people in the organization feel that they have been treated fairly in their place of work. Based on the opinion of experts, it can be synthesized that organizational justice is a level where an individual feels treated the same or equal in the organization where he works with indicators (a) distributive justice (b) procedural justice (c) informational justice (d) Interpersonal justice.

\section{Methodology}

This study uses a quantitative method with a correlation survey model. The independent variable in this study is personality $\left(X_{1}\right)$ and organizational justice $\left(X_{2}\right)$, while the dependent variable $(Y)$ is the quality of teacher services. The population in this study were 279 state high school civil servant teachers in the city of Bogor. The sample in the study was calculated using the Slovin formula as many as 103 people. The sampling technique uses Multistage Sampling. The first stage is a cluster, the second stage is purposive and the third stage is taking samples at each school which is carried out using a proportional random sampling technique.

Quantitative research data were analyzed using descriptive statistics and inferential statistics. Inferential statistics using regression-correlation analysis. The data analysis was performed by using the normality test step of the estimation error, the homogeneity test of variance. Determination of the regression equation, the regression equation significance test, regression linearity, and hypothesis testing using the correlation test. The qualitative data analysis process was carried out in two stages, namely the analysis during the data collection process in the field and the analysis after data 
collection by comparing the data value of each item using the SITOREM method.

\section{RESULTS AND DISCUSSION}

\section{A. Results}

\section{1) Normality Test}

The results of the calculation of the normality test of the estimation error $(\mathrm{Y}-\hat{\mathrm{Y}} 1)$ for the variable of teacher service quality on the teacher personality variable obtained the $L_{\text {count }}$ value of 0.060 while the $L_{\text {table }}$ was 0.080 . The normal requirement is $L_{\text {count }}<L_{\text {table, }}$, thus the standard error of estimation $(\mathrm{Y}-\hat{\mathrm{Y}} 1)$ for the variable of teacher service quality on teacher personality variables is normally distributed.

The results of the calculation of the normality test of the estimation error $(\mathrm{Y}-\hat{\mathrm{Y}} 2)$ for the variable of teacher service quality on the variable of organizational justice obtained the $L_{\text {count }}$ value of 0.070 while the $L_{\text {table }}$ was 0.080 . The normal

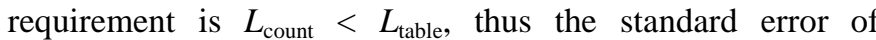
estimation $(\mathrm{Y}-\hat{\mathrm{Y}} 2)$ for the variable of teacher service quality on organizational justice variables is normally distributed.

\section{2) Homogeneity Test}

The homogeneity of the variance of the variable of teacher service quality on the teacher's personality obtained the value of ${ }^{2}$ count 27.82 , while ${ }^{2}$ table at $\alpha=0.05$ was 47.39 . Thus the data variance of the variable teacher service quality on the teacher personality variable was declared homogeneous.

The homogeneity of the variance of the variable of teacher service quality on organizational justice obtained the value of count 46.28 , while ${ }^{2}$ table at $\alpha=0.05$ was 55.75 . Thus the variance of the data on the variable of teacher service quality on the variable of organizational justice is stated to be homogeneous.

\section{3) Hypothesis Test}

The correlation between the teacher personality variable (X1) and the service quality variable $(\mathrm{Y})$ is determined by the coefficient of determination $(\mathrm{r} 2 \mathrm{y} 1)$. Based on the estimation results, the r2y1 value is 0.177 . These results indicate that $18 \%$ of the teacher service quality variable (Y) can be influenced by the teacher personality variable (X1). The relationship resistance of the teacher personality variable (X1) with the teacher service quality variable $(\mathrm{Y})$ is determined by the correlation coefficient ry1 of 0.421 .

Based on the results of the correlation test, it can be seen that the $t_{\text {count }}$ is 5.15 while the $t_{\text {table }}$ is 1.98 . This shows that the correlation coefficient of the teacher personality variable (X1) with the teacher service quality variable $(\mathrm{Y})$ is significant. Based on the test results it can be concluded that there is a positive relationship between the teacher personality variable (X1) and the teacher service quality variable (Y).

The correlation of the organizational justice variable (X2) with the teacher service quality variable $(\mathrm{Y})$ is determined by the coefficient of determination (r2y2). Based on the estimation results, the $\mathrm{r} 2 \mathrm{y} 2$ value is 0.089 . These results indicate that $9 \%$ of the teacher service quality variable $(\mathrm{Y})$ can be influenced by the organizational justice variable (X2). The resistance to the relationship between the organizational justice variable (X2) and the teacher service quality variable (Y) is determined by the correlation coefficient ry2 of 0.297 .

Based on the results of the correlation test, it can be seen that the $t_{\text {count }}$ is 3.28 while the $t_{\text {table }}$ is 1.98 . This shows that the correlation coefficient of the organizational justice variable (X2) with the teacher service quality variable $(\mathrm{Y})$ is significant. Based on the test results, it can be concluded that there is a positive relationship between the organizational justice variable (X2) and the teacher service quality variable (Y).

The correlation of teacher personality variables (X1) and organizational justice (X2) together with teacher service quality $(\mathrm{Y})$ is determined by the value of the coefficient of determination ( 2 2y12). Based on the estimation results, the $r_{2} y_{12}$ value is 0.179 . These results indicate that $18 \%$ of the teacher service quality variable (Y) can be influenced by the teacher personality variable (X1) and organizational justice (X2). The resistance of the relationship between the teacher personality variable (X1) and organizational justice (X2) together with the teacher service quality variable $(\mathrm{Y})$ is determined by the correlation coefficient ry12 of 0.423 .

Based on the results of the regression test, it can be seen that $F_{\text {count }}$ is 7.30 while $F_{\text {table }}$ is 3.08 . This shows that the correlation coefficient of teacher personality (X1) and organizational justice (X2) together with the variable teacher service quality ( $\mathrm{Y}$ ) is significant. There is a positive relationship between teacher personality variables (X1) and organizational justice (X2) together with the variable teacher service quality (Y). Based on the test results, it can be concluded that there is a positive relationship between teacher personality variables (X1) and organizational justice (X2) together with the variable teacher service quality (Y).

\section{4) Partial Correlation Test}

The results of the calculation of the first partial correlation test, the partial correlation value of teacher personality (X1) with the quality of teacher service (Y) with control on organizational justice $(\mathrm{X} 2)$ (ry12) $=0.215$ is obtained. Based on the results of the significance test, this value is significant (th $=2.27>\mathrm{tt}=1.98(\alpha=0.05)$. So the relationship between teacher personality and teacher service quality is not influenced by organizational justice variables.

The calculation of the second partial correlation test, the partial correlation value between organizational justice (X2) and the quality of teacher service $(\mathrm{Y})$ is obtained with the control on teacher personality $(\mathrm{X} 1)($ ry 12$)=0.084$. This value is very significant $(\mathrm{th}=0.86<\mathrm{tt}=1.98(\alpha=0.05)$. Thus, it can be concluded that the relationship between organizational justice and the quality of teacher service is influenced by the teacher personality variable.

\section{B. Discussion}

\section{1) The Relationship between Teacher Personality and Quality of Teacher Service}

The strength of the relationship between teacher personality and teacher service quality can be seen in the results of the correlation test with a correlation coefficient of 0.421 . The 
diversity that exists in the quality of teacher services is related to the personality of the teacher as seen from the coefficient of determination of 0.177 so that the diversity in the quality of teacher services can be explained by the personality of the teacher with a contribution of $18 \%$. Meanwhile, $82 \%$ are influenced by other factors outside the teacher's personality. Personality is the character, behavior pattern, thoughts, and emotions of an individual that is unique and relatively stable. A good teacher personality will improve the quality of teacher services. It can be concluded that there is a positive relationship between teacher personality and teacher service quality, so that teacher personality is an important factor in improving the quality of teacher service.

2) The Relationship between Organizational Justice and Teacher Service Quality

The strength of the relationship between organizational justice and the quality of teacher services can be seen in the results of the correlation test with a correlation coefficient of 0.297 . The diversity that exists in the quality of teacher services is related to organizational justice seen from the coefficient of determination of 0.089 so that the diversity that exists in the quality of teacher services can be explained by organizational justice with a contribution of $9 \%$. Meanwhile, $91 \%$ is influenced by other factors outside of organizational justice. This is consistent with the statement by Kreitner and Kenicki (2007) that organizational justice in schools reflects the extent to which people in the organization feel that they have been treated fairly in their place of work.

Based on these results, organizational justice can affect the quality of teacher services. When someone feels that they are treated fairly and feel comfortable in a work environment, the quality of service will increase. It can be concluded that there is a positive relationship between organizational justice and teacher service quality so that organizational justice is an important factor in improving the quality of teacher services.

3) The Relationship between Teacher Personality and Organizational Justice together with the Quality of Teacher Services

The strength of the relationship between teacher personality and organizational justice together with the quality of teacher service can be seen in the results of the correlation test with a correlation coefficient of 0.179 . The diversity that exists in teacher service quality has a relationship with teacher personality and organizational justice seen from the value of the coefficient of determination of 0.423 so that the diversity that exists in teacher service quality can be explained by teacher personality and organizational justice with a contribution of $18 \%$. collectively by teacher personality and organizational justice.

From the research results, it will be shown that there is a positive influence on the dependent variable with the correlation coefficient $\rho y 1$, $\rho y 2$, and $\rho y 12$ for each variable. Besides, to see how much the strength of the relationship between the independent variable and the dependent variable and to get the optimal solution from this study and to optimize each indicator for each research variable was carried out by giving weight to each indicator, based on Scientific Introduction to Research Operations in the field of Education Management or known as SITOREM (Hardhienata, 2017) as shown in Table I.

TABLE I

CORRELATION COEFFICIENT CALCULATION RESUlTS

\begin{tabular}{ccc}
\hline $\begin{array}{c}\text { Correlation } \\
\text { Coefficient }\end{array}$ & $\begin{array}{c}\text { Correlation } \\
\text { Coefficient Value }\end{array}$ & $\begin{array}{c}\text { Relationship } \\
\text { Strength Level }\end{array}$ \\
\hline ry1 & 0.421 & Strong enough \\
ry2 & 0.297 & Less strong \\
ry12 & 0.423 & Strong enough \\
\hline
\end{tabular}

\section{CONCLUSIONS}

The results showed that there was a positive relationship between teacher personality and teacher service quality with the strength of the relationship ry1 $=0.421$ and there was a positive relationship between organizational justice and teacher service quality with the strength of the relationship ry2 $=0.297$. This reflects that improving the quality of teacher services can be done by improving teacher personality and organizational justice. Indicators that have been well maintained or developed and indicators that have not been properly improved.

The results of SITOREM's analysis show that the components of teacher personality, organizational justice, and quality of teacher services are found in 9 indicators that are in good condition so that it remains to be maintained, namely: (1) sincerity (2) enthusiasm (3) consensus (4) interpersonal justice (5) justice informational (6) distributive justice (7) physical appearance (8) guarantee (9) reliability. While 5 components still need to be improved, there are 5 components in order of priority for improvement, namely: (1) stable emotions (2) open to experience (3) justice procedural (4) responsiveness (5) attention. Indicators that still need to be improved need attention so that the quality of teacher services will increase.

\section{ACKNOWLEDGMENT}

This research was carried out with Grant Funds from the Directorate of Community Service Research, Directorate General of Research and Development Strengthening of the Ministry of Research and Technology following the implementation year 2020 based on Funding Agreement between L2Dikti4 Office and Pakuan University Number: 114/AMD/SP2H/LT /MONO/LL4/PP/ 2020 April 1st, 2020. Thus we thank the Kemenristekdikti/BRIN for funding.

\section{REFERENCES}

Akanbi, Paul., Ofeogbu, Ayobami., \& Eugene, Onyema. (2013). Impact of perceived Organizational Justice on Organizational Commitment of a Food and Beverage Firm in Nigeria. International Journal of Humanities and Social Science, 3(14), 217-218.

Baines, Paul., Fill, Chris., \& Page, Kelly. (2011). Marketing. New York: Oxford University Press. pp. 503-505.

Baldwin, Susanna. (2006). Organizational Justice. Brigton Institute For Employment Studies. pp.1-13. 
Colquitt, Jason., Lepine, Jeffrey A., \& Wesson, Michael J. (2015). Organizational Behavior, Improving Performance, and Commitment in the Workplace. New York: Mc Graw Companies, Inc. pp. 224-233.

Crae, Mc \& Costa, Robert. (2012). Personality in Adulthood, Second Edition. A five Factor Theory Perspective, Edition 2. Guilford Press.

Demirel, Yavuz \& Yucel, Ilhami. (2013). The Effect Of Organizational Justice on Organizational Commitment: A Study on Automotive Industry. International Journal of Social Sciences, 11(3), 2637.

Gibson, James L. Ivancevich, John M. Donnely, James H., \& Konospake, Robert. (2012). Organizations Behavior, Structure, Processes 14th Ed. New York: Mc GrawHill). pp. 148-150.

Greenberg, Jerald \& Baron, A. Robert. (2008). Behavior in organizations. New Jersey: Pearson Educational International. pp. 45-53.

Hardhienata, Soewarto. (2017). The Development Of Scientific Identification Theory to Conduct Operation Research in Education Management. IOP Conference Series: Material Science and Engineering, 166.

Helriegel, Don \& Scolum, John. (2011). Organizational Behavior, 13th edition. South -Western: Changage learning. pp. 70.

Hussain, Kabir. (2010). Service Quality; Expectations, perceptions, and satisfaction about Service Quality at Destination Gotland- a case study. Gotland University: Masters program in international Management 15 ETCS, pp. 27-29.

Kotler, P. (2000). Marketing Management. Upper Saddle River, NJ: Prentice-Hall.

Kreitner, Robert \& Kinichi, Angle. (2007). Organizational Behavior. New York: Mc Graw-Hill. pp. 244-245.

Nagabushanam, Manasa. (2013). A Studi On Customer Service Quality of Banks in India. Bangalor, Analyze Research Solution Pvt. Ltd. pp. 318.

Peter, J. Paul \& Donnely, H. James, Jr. (2011). Marketing Management Knowledge And Skills, Eleventh Edition. USA: McGraw-Hill.

Robbins, Stephen P. \& Judge, Timothy A. (2009). Perilaku Organisasi. Jakarta: Salemba Empat. pp. 249-251.

Suzane, De Janasz., Dowd, Karen., \& Schneider, Beth Z. (2006). Interpersonal Skills in Organizations. New York: Mc Grow-Hill. pp. 112-116.

Yosliogu, Murat., Caliskan, Ozaslan Burcu., \& Omer. (2013). The Role of Innovation and Perceived Quality in Creating Customer Value. Procedia - social and behavioral sciences, rights/2017/02/27/childmarriage-bill-passed/. 